\title{
Organizational Citizenship Behaviours - Antecedents, Outcomes \& Paradoxes: A Literature Review
}

\author{
Aniisu Verghese*
}

\begin{abstract}
Organizational Citizenship Behaviours(OCBs) have a significant impact on how employees go over and beyond at the workplace and form a competitive edge for their firms. Grounded in industrial-organizational psychology, OCBs provide insights for leaders and managers to align and engage staff to improve organizational effectiveness. While a lot of studies have focused on the benefits of citizenship behaviours, there are paradoxes which need more attention. This paper reviews the literature on OCBs, the antecedents, outcomes and paradoxes when excessive OCBs can come in the way of organizational success.
\end{abstract}

Keywords: Organizational citizenship behaviours, deviant behaviours, compulsory citizenship behaviours, organizational effectiveness

\section{Introduction}

Organizational Citizenship Behaviours (OCBs) isan important subject of study inorganizational behaviour and industrialorganizational psychology. (Bateman \& Organ, 1983; Smith, Organ, \& Near, 1983; Kandlousi, Ali\& Abdollahi, 2010; Chan\& Lai, 2017).

OCBs go beyond the responsibilities attached to job roles, and therefore when employees exhibit these behaviours, it is expected to positively impact measures of organizational effectiveness.

"PhD Research Scholar Alliance University, Bengaluru, India; aniisu3@gmail.com 
(Bateman \& Organ, 1983; Smith, Organ, \& Near, 1983; Podsakoff, Whiting, Podsakoff, \& Blume, 2009). The study of OCB follows the observation by Katz \& Kahn (1978) that an organization is formed by social lubrication as in, "acts or behaviours of people acting on materials, machines and interacting with each other. Such behaviours are disembodied and not anonymous." Employees' job performance is of utmost significance for the organization to be successful, and Bateman \& Organ (1983) argue that the definition of performance lacked clarity leading to confusion that satisfaction causes performance. They predicted that satisfaction did lead to a connection with a host of citizenship behaviours which led to improved productivity.

\section{Literature Review}

The literature review shows that past studies on OCBs result from an attempt to understand how discretionary work behaviours are not acknowledged by the formal reward system that exists within organizations yet contributes to its overall effectiveness and performance. Literature is categorized into the following broad segments - studies that focus on OCBs and their antecedents, OCBs and outcomes and OCBs and paradoxes.

\subsection{Dimensions of OCB}

OCB as a construct was defined by Dennis Organ and his coauthors (Bateman \& Organ, 1983; Smith et al., 1983) as "individual behaviour that is discretionary, not directly or explicitly recognized by the formal reward system, and that in the aggregate promotes the effective functioning of the organization" (Organ, 1997). Citizenship behaviours are under the voluntary control of individuals, and such prosocial gestures are also called 'supra-role behaviours' - behaviours that cannot be prescribed or required in advance for a given job (Bateman \& Organ, 1983). Examples of such behaviours include helping co-workers in job-related areas, not complaining when given orders, coping with bottlenecks, keeping the workplace orderly, providing timely and supportive feedback to improve, building a conducive workplace and ensuring the organization is always protected. 
In their study among employees and supervisors in two banks, Smith et al. (1983) suggested two dimensions of OCB - altruism and generalized compliance. The former referred to the act of helping certain individuals and the latter, referred to conscientiousness that aligned with organizational guidelines. Leader supportiveness showed a direct effect on generalized compliance. Satisfaction has some direct effect on some forms of citizenship behaviour. The study prescribes that continuing to study citizenship behaviour in the work setting was meaningful. (Organ, 1988) cited in Podsakoff et al.(2009) expanded the dimensions of OCB to include altruism, conscientiousness, sportsmanship, courtesy, civic virtue. Sportsmanship refers to tolerance on the part of employees to less than ideal situations at the workplace and refusing to make large issues of small concerns. Civic virtue is the behaviour indicating that employees took an active interest in the life of their organization. Conscientiousness (also known as compliance) is about the behaviour that aligns with the rules and guidelines prescribed by the organization. Courtesy refers to behaviour aimed at preventing conflicts amongcoworkers.

Scholars have also addressed patterns of prescribed and discretionary behaviours that support the organization and labelled and operationalized the construct as contextual performance (Borman and Motowildo, 1993 cited in LePine, Erez, \& Johnson, 2002) and organizational spontaneity (George and Brief, 1992). These constructs are closely related, although they differ in their definition and applicability. Individual performance is understood as either task performance or contextual performance. The former refers to the core technical functions of individual behaviour while the latter is considered as elements of individual performance that refers to behaviours that do not support the technical core itself so much as they support the broader organizational, social, and psychological environment in which the technical core must function (Van Dick, Grojean, Christ, \&Wieseke, 2006; Borman and Motowildo, 1993 cited in Organ, 1997). OCB and contextual performance are similar to the extent that they include behaviours that go over and above the routine expectations of jobs. OCB arebehavioural manifestations of a positive collaborative effort at the workplace and (LePineet al., 2002) recommended redefining the 
construct as 'a general tendency to be cooperative and helpful in organizational settings'.

Organizational spontaneity, a similar construct (George and Brief, 1992) is defined as 'extra-role behaviours that are performed voluntarily and that contributes to organizational effectiveness'. Five forms of organizational spontaneity are helping co-workers, protecting the organization, making constructive suggestions, developing oneself and spreading goodwill. In contrast,OCB includes role prescribed and extra role active and passive behaviours that are not recognized by the reward system while organizational spontaneity only considers extra-role, active behaviours recognized by a formal reward system.

Table2.1: Summary of key studies in OCB related to criterion and rating source

\begin{tabular}{|c|c|c|c|c|}
\hline Study setting & $\begin{array}{c}\text { Sample } \\
\text { characteristics }\end{array}$ & $\begin{array}{l}\text { Unit of } \\
\text { study }\end{array}$ & $\begin{array}{c}\text { Rating } \\
\text { source/N }\end{array}$ & Authors \\
\hline $\begin{array}{l}2 \text { banks of a } \\
\text { large mid- } \\
\text { western city } \\
\text { in the US }\end{array}$ & $\begin{array}{l}\text { Representing } 77 \\
\text { departments }\end{array}$ & $\begin{array}{l}\text { Employees } \\
\text { and } \\
\text { supervisors }\end{array}$ & $\begin{array}{l}422 \\
\text { employees } \\
\text { and their } 67 \\
\text { supervisors }\end{array}$ & $\begin{array}{l}\text { Smith } \\
\text { et al., (1983) }\end{array}$ \\
\hline US Army & $\begin{array}{l}\text { Different } \\
\text { departments }\end{array}$ & Soldiers & $\begin{array}{l}140 \text { enlisted } \\
\text { men and } \\
\text { officers }\end{array}$ & $\begin{array}{l}\text { Turnipseed } \\
\text { (1996). }\end{array}$ \\
\hline $\begin{array}{l}\text { University in } \\
\text { the US }\end{array}$ & $\begin{array}{l}\text { Two groups of } \\
\text { undergraduate } \\
\text { students } \\
1^{\text {st }} \text { group - } \\
\text { between the } \\
\text { ages 18-25 } \\
\text { years. }\end{array}$ & students & $\begin{array}{l}\text { - 1st group } \\
616 \text { and } 2^{\text {nd }} \\
\text { group of } 178 \\
\text { under- } \\
\text { graduates }\end{array}$ & $\begin{array}{l}\text { Rioux\& } \\
\text { Penner } \\
(2001)\end{array}$ \\
\hline
\end{tabular}

\subsection{OCB and Antecedents}

A range of employee, team, organizational and leadership factors are known to predict different types of OCB in varied situations. Studies refer to many possible predictors of OCB with varying ranges of reliability measures: organizational identification (Christ, Dick, Wagner \&Stellmacher, 2003), job satisfaction (Bateman \& Organ, 1983), leader supportiveness (Smith et al., 1983), communication satisfaction (Kandlousi et al., 2010) and perceived justice (Chan \& Lai, 2017). 
In a study in German schools, (Christ et al., 2003) teachers exhibited extra-role behaviours at the individual, team, and organizational levels.These different forms of OCB correlate with various forms of identification. They observed an $18 \%$ variance in OCB to own career identification, $35 \%$ variance in OCB on team identification and $43 \%$ in OCB on behalf of the organization indicating that identification is an important variable that impacts differences in OCB.

Likewise, Podsakoff et al., (2009) discovered through a metaanalysis that individual level OCB were positively related to ratings of employee performance and reward allocation decisions and negatively related to employee turnover intentions, actual turnover and absenteeism. At the unit level, OCBs were positively related to organizational effectiveness measures and customer satisfaction and negatively related to costs and unit-level turnover. When managers encourage employees to exhibit OCBs, there is a greater propensity that job performance and therefore, organizational performance will improve.

\subsection{OCBs and Outcomes}

OCBs are considered important behaviours, leading to organizational performance and success (Christ et al., 2003; Podsakoff et al.,2009; Kandlousi et al., 2010). Such behaviours are valued at the workplace because it makes the lives of supervisors easier, frees up time and effort to do other critical work and also it can't be expected from employees since it is discretionary (Bateman \& Organ, 1983). How organizations influence employees' behaviours to go over and above on the job is a key differentiator and a competitive edge which can't be replicated (Bolino\&Turnley, 2003).

OCB influences the achievement of organizational goals and organizational performance and occurs at different levels. (Bolino\&Turnley, 2003; Christ et al., 2003; Podsakoff et al.,2009). OCB leads to increased business performance, more productivity, better quality and quantity and creation of social capital among employees. Also, units which have higher levels of OCB were seen to be more profitable. (Bolino\&Turnley, 2003). 
When scholars conducted a meta-analysis, they found that OCBs were positively related to individual and unit-level performances. OCBs were positively related to ratings of employee performance at the individuallevel, and to reward allocation decisions and negatively related to employee turnover intentions, actual turnover and absenteeism. At the unit level, OCBs were positively related to organizational effectiveness measures and customer satisfaction and negatively related to costs and unit-level turnover. (Podsakoff et al., 2009).

In another meta-analysis (LePine et al., 2002) found that the OCB was a latent construct and that there were strong relationships between most of the dimensions. Also, dimensions had similar relationships between the predictors - satisfaction, organizational commitment, fairness, leader support and conscientiousness. Literature indicates that people demonstrate OCB when they are satisfied with their job and their supervisors (Bateman \& Organ, 1983). In their study among employees in a major state university, Bateman \& Organ (1983) discovered that the immediate supervisor contributed the most in terms of the influence that led to positive intent towards citizenship behaviours. Relationship between OCB and job satisfaction is known to be twice as stronger than job satisfaction and employee productivity. (Bolino\&Turnley, 2003).

Studies have been conducted among a variety of audiences such as schoolteachers, contingent workers and retail staff members (Van Dyne \& Ang 1998; Christ et.al., 2003; Ackfeldt\&Coote, 2005). In a study among contingent service workers in Singapore, it was found that they exhibited less citizenship behaviour, expected less from their employers and had lower commitment levels. However, when they are treated well, have high commitment and positive attitudes.There is a possibility of them contributing more positively with reciprocal citizenship behaviours. (Van Dyne \& Ang, 1998). Among German schoolteachers, OCB was impacted by different levels of identification-career, team and organizational. Identification emerged as an important variable that impacts differences in OCB with social identity theory working in the school environment. (Christ et al., 2003). In the retail setting, positive linkages were observed between job attitudes and OCBs. A feeling of job satisfaction and commitment to the organization are 
prerequisites for citizenship behaviours. The implications for managers are to build OCBs, and positive job attitudes should view leadership support, professional development and empowerment as key strategic approaches for managing frontline employees. (Ackfeldt\&Coote, 2005).

Every organization depends on various acts of goodness and support that are not governed by direct or indirect forms of coercion at the workplace and yet are crucial for its success. Therefore, understanding the ways to increase OCB is critical. Among the factors that promote OCB include job satisfaction, transformational and supportive leadership, interesting work and job involvement, organizational support, trust, organizational justice, psychological contract fulfilment, employee characteristics. (Bolino\&Turnley, 2003). By focusing on managing human capital rather than the economic principles of cost reduction, efficiency and cash flow there are more chances that employees will be proactive, drivenpartner, and be committed to high performance and standards. (Drucker, 1999; Bakker \& Schaufeli, 2008).

Bolino\&Turnley (2003) suggest that OCB can be enhanced through formal HRM practices such as recruitment and selection. Candidates with active participation in lives beyond their academic institutions need to be given more consideration and informal systems such as rewards that enable employees to be good citizens. These should be incorporated such that the organization benefits from OCB exhibited by its employees (Mazzei, 2014). The key point is to focus on the extent to which employees exhibit these behaviours and not what they have as traits when evaluating their performance.

\subsection{OCBs and Paradoxes}

Since Organ and his co-authors introduced OCB to organizational research (Bateman \& Organ, 1983; Smith et al., 1983) studies have discussed the positive contributions of employees and the organization. Some scholars have, however, noted how OCBs couldbe perceived as negative and harmful for the organization unless preventative measures are adopted.

Scholars have indicated that OCB shouldn't be viewed in place of traditional job performance, and therefore, the priority is for 
employees to focus on delivering their work responsibilities. (Bolino\&Turnley, 2003). However, there is a dilemma in the minds of employees because at times, engaging in OCB can come at the cost of task performance, hurting opportunities to grow in their careers (Bergeron, 2007). From a resource allocation perspective, the trade-off can also harm the organization when the individuals avoid contributing to OCB when they know it will lower their chances of success. The downsides of excessive OCB are called escalating citizenship (Bolino\&Turnley, 2003) where employees feel the pressure to continually increase their citizenship to feel they are going over and beyond at the workplace (Bolino, Turnley, Gilstrap, \& Suazo, 2010).The dark side of OCB is highlighted by deviant behaviours often triggered by abusive and exploitive expectations by supervisors (Vigoda-Gadot, 2006). In a study among teachers in Israel, a varied majority reported strong pressure to exhibit what the author coins as compulsory citizenship behaviour.

Suggestions are offered by scholars for organizations to avoid emphasis on OCB because it may lead to the employee ignoring job responsibilities. Likewise, by focusing rewards on collaboration and teamwork employees will begin to pay more attention to supportive behaviours. Also, when managers reward employees for engaging in positive behaviours rather than competitive and non-cooperative behaviours, the message will be understood better. When organizations perceive that OCBs are leading to stress, fatigue, burnout and exhaustion among employees, they need to take stock of the situation to avoid turnover and unhealthy competition. (Bolino,Hsiung, Harvey, \& LePine, 2015)Impression management - activities that help enhance one's image among peers or managers are known to be a motive for employees and an important force to underscore OCB (Bolino\&Turnley, 2003). The author provides a framework to gauge which employee is a good actor or a good soldier and therefore allow organizations to confirm the appropriate acts of citizenship. In a study among municipal employees to gauge citizenship motives such as prosocial values, organizational concern and impression management the authors (Rioux\& Penner, 2001) discovered no significant correlation between the OCB dimensions and impression management. It also indicated that motives play an important role in $\mathrm{OCB}$, and the study highlighted that individuals 
prefer to engage in OCB because it was self-serving and helped them achieve their purpose.

Bolino\&Turnley (2003) argue that the costs of citizenship can exceed the benefits when employees engage in behaviours at the expense of their regular duties and too much OCB seen at the workplace can mean that the organization needs to staff itself appropriately.

In summary, OCBs are critical for the smooth functioning and success of organizations. It is dependent on employees to perform tasks that go beyond their normal job expectations. Where they cooperate, learn others' expectations, accept and fulfil the assignments in close collaboration. There are downsides of excessive $\mathrm{OCB}$, and it can hurt the employee and the organization unless addressed. How and in what way they contribute to citizenship behaviours has an impact on the organization's future. As Katz \& Kahn (1978) stated that "human organizations are viewed as a system of roles and how tasks in roles are allocated and made motivating to fulfil the requirements is what makes the organizations successful".

\section{References}

Ackfeldt, A. L., \& Coote, L. V. (2005). A study of organizational citizenship behaviors in a retail setting. Journal of Business Research, 58(2), 151-159.

Bakker, A. B., \& Schaufeli, W. B. (2008). Positive Organizational Behavior: Engaged Employees in Flourishing Organizations. Journal of Organizational Behavior: The International Journal of Industrial, Occupational and Organizational Psychology and Behavior, 29(2), 147-154.

Bateman, T. S., \& Organ, D. W. (1983). Job satisfaction and the good soldier: The relationship between affect and employee "citizenship". Academy of Management Journal, 26(4), 587-595.

Bergeron, D. M. (2007). The Potential Paradox of Organizational Citizenship Behavior: Good citizens at what cost? Academy of Management Review, 32(4), 1078-1095.

Bolino, M. C., \& Turnley, W. H. (2003). Going the extra mile: Cultivating and managing employee citizenship behavior. Academy of Management Perspectives, 17(3), 60-71. 
Bolino, M. C., Turnley, W. H., Gilstrap, J. B., \& Suazo, M. M. (2010). Citizenship under pressure: What's a "good soldier" to do?. Journal of Organizational Behavior, 31(6), 835-855.

Bolino, M. C., Hsiung, H. H., Harvey, J., \& LePine, J. A. (2015). “Well, I'm tired of tryin'!" Organizational citizenship behavior and citizenship fatigue. Journal of Applied Psychology, 100(1), 56.

Chan, S. H. J., \& Lai, H. Y. I. (2017). Understanding the link between communication satisfaction, perceived justice and organizational citizenship behavior. Journal of Business Research, 70, 214-223.

Christ, O., Van Dick, R., Wagner, U., \& Stellmacher, J. (2003). When teachers go the extra mile: Foci of organizational identification as determinants of different forms of organizational citizenship behaviour among schoolteachers. British Journal of Educational Psychology, 73(3), 329-341.

Drucker, P. F. (1999). Knowledge-worker productivity: The biggest challenge. California Management Review, 41(2), 79-94.

George, J. M., \& Brief, A. P. (1992). Feeling good-doing good: a conceptual analysis of the mood at work-organizational spontaneity relationship. Psychological Bulletin, 112(2), 310.

Kandlousi, N. S. A. E., Ali, A. J., \& Abdollahi, A. (2010). Organizational citizenship behavior in concern of communication satisfaction: The role of the formal and informal communication. International Journal of Business and Management, 5(10), 51.

Katz, D. \&Kahn, R. L (1978). The Social Psychology of Organizations,2. New York: Wiley.

LePine, J. A., Erez, A., \& Johnson, D. E. (2002). The nature and dimensionality of organizational citizenship behavior: a critical review and meta-analysis. . Journal of Applied Psychology, 87(1), 52.

Mazzei, A. (2014). Internal communication for employee enablement: Strategies in American and Italian companies. Corporate Communications: An International Journal, 19(1), 82-95.

Organ, D. W. (1997). Organizational citizenship behavior: It's construct clean-up time. Human Performance, 10(2), 85-97.

Podsakoff, N. P., Whiting, S. W., Podsakoff, P. M., \& Blume, B. D. (2009). Individual-and organizational-level consequences of organizational citizenship behaviors: A meta-analysis. Journal of Applied Psychology, 94(1), 122.

Rioux, S. M., \& Penner, L. A. (2001). The Causes of Organizational Citizenship Behavior: a Motivational Analysis. Journal of Applied Psychology, 86(6), 1306.

Smith, C. A., Organ, D. W., \& Near, J. P. (1983). Organizational Citizenship Behavior: Its Nature and Antecedents. Journal of Applied Psychology, 68(4), 653. 
Van Dick, R., Grojean, M. W., Christ, O., \& Wieseke, J. (2006). Identity and the extra mile: Relationships between organizational identification and organizational citizenship behaviour. British Journal of Management, 17(4), 283-301.

Van Dyne, L., \& Ang, S. (1998). Organizational citizenship behavior of contingent workers in Singapore. Academy of Management Journal, 41(6), 692-703.

Vigoda-Gadot, E. (2006). Compulsory Citizenship Behavior: Theorizing Some Dark Sides of the Good Soldier Syndrome in Organizations. Journal for the Theory of Social Behaviour, 36(1), 77-93. 